\section{CONRAD GESNER AND JOHANN 116 JACOB SCHEUCHZER}

ON September 7 there hundredth annilexury of the founding of the Zurich Society of Naty al Sciences. The Swiss Society of Natural fciepces Nold its 126th annual meeting at the sameltine, and the attendance of delegates from some thirty other countries fonfered upon the Congress an international signiAance.

After addresses by the president, Prof. P. Niggli, professor of mineralogy and petrography in the University of Zurich, and by several of the foreign delegates, Prof. Hans Fischer, professor of pharmacology, delivered an address on the lives and works of two distinguished sons of Zurich, Conrad Gesner and Jacob Scheuchzer, each of whom occupied the position of town physician and greatly advanced the science of his time. The current issue of the Swiss scientific journal Atlantis contains not only some extracts from the correspondence of Gesner and Scheuchzer with their English friends but also a number of the remarkable illustrations which adorn Scheuchzer's principal work, "Physica Sacra".

Conrad Gesner (1516-65) was the pioneer of humanism in Zurich at the time of the great movements of the Renaissance and Reformation. That he was a man of immense industry is shown by his "Bibliotheca Universalis", published in 1545, a ciatalogue of all the writings in Hebrew, Greek and Latin which had appeared prior to that date. This great task completed, Gesner next set himself to describe, in systematic and scientific fashion, every known animal and plant. His "Historia Animalium", the first volume of which was issued in 1551 , forms part of the basis of modern zoology, and contains a number of wood-cuts by Albrecht Dürer. The botanical part of this wide scheme of research, "Historia Plantarum", was incomplete when Gesner died. $\mathrm{He}$ was widely known for his writings, not merely in science but also in medicine, and he was held in high esteem as a physician.

Gesner's death from plague at the age of fifty-nine was indeed a great loss to science and medicine alike. Among the friends who mourned him was John Caius of Cambridge, who had written, at Gesner's request, his monograph on British / dogs, "De Canibus Brittanicis", and there were many others, since Gesner's house in Zurich was a meeting-place for scholars from all quarters.

A century later there was born another notable pioneer who became town physician of Zurich, Johann Jacob Scheuchzer (1672-1733). Scheuchzer lived at a time when the progress of science was greatly retarded by the rigid orthodoxy of the Church. Nevertheless, he was the first to describe, in a comprehensive and scientific fashion, the physical geography of the Swiss Alps, and he made many original observations on the meteorology, geology, botany and zoology of Switzerland. Those numerous observations, the ressults of many journeys in all parts of the country, led to the publication of his "Natur. geschichte des Schweitzerlandes" (1706-08) and "Herbarium Diluvianum" (1709), but his greatest work is contained in the four folio volumes entitled "Physica Sacra" (1731-35). They form a sort of commentary on the Old Testament such as could not fail to be accepted by the most bigoted churchmen of the day, without any sacrifice of scientific accuracy.
Of outstanding interest are Scheuchzer's descriptions of fossil plants and animals and of Homo diluvii testis (the skull of a 'Rhinelander' man), the relics of an earlier flora and fauna which, he said, had been preserved beneath the waters of the Flood. The engravings which adorn this work are of great artistic merit. In medicine, Scheuchzer was less distinguished than Gesner, although in science he was a worthy follower-one of the leading pioneers in the wide field of natural philosophy.

DOUGLAS GUTHRIE

\section{DENTAL CONDITION OF FIVE- YEAR-OLD ELEMENTARY SCHOOL CHILDREN}

\section{BY $D_{R}$. HELEN COUMOULOS Girton Crillege, Cambridge}

A FIELD surfey of the dental condition of more than 4.000 five-year-old elementary school children ix various parts of England and of a few in Wales was undertaken during the years 1943-45. In the course of the survey the surface structure, the incidence and extent of caries, the 'healing' or arrest of the carious process and other conditions were carefully recorded on suitable charts. The standards used were those devised in 1927 by M. Mellanby ${ }^{1}$.

The main results of this investigation are presented in the accompanying table, in the hope that they may be of interest to other workers and may serve as a basis for comparative study with future surveys of a similar nature. It must be emphasized, however, that when making such comparisons it is essential that the same standards should be used. Detailed analyses of some of the data obtained are in the press, and others will be published in the near future.

THE DECIDUOUS TEETH OF FIVE-YEAR-OLD ELEMENTARY SCHOOI CHILDREN 1943 TO 1945

\begin{tabular}{|c|c|c|c|c|c|}
\hline \multirow[b]{2}{*}{ Districts } & \multirow[b]{2}{*}{$\begin{array}{c}\text { Number } \\
\text { of } \\
\text { children } \\
\text { in- } \\
\text { spected }\end{array}$} & \multicolumn{2}{|c|}{ Hypoplasia } & \multicolumn{2}{|c|}{ Caries } \\
\hline & & $\begin{array}{l}\text { Percent- } \\
\text { age of } \\
\text { teeth } \\
\text { with } \\
M \text {-hypo- } \\
\text { plasia }\end{array}$ & $\begin{array}{l}\text { Percent- } \\
\text { age of } \\
\text { teeth } \\
\text { with } \\
\text { 'text- } \\
\text { book' or } \\
\text { G-hypo- } \\
\text { plasia* }\end{array}$ & $\begin{array}{l}\text { Percent- } \\
\text { age of } \\
\text { teeth } \\
\text { carious }\end{array}$ & $\begin{array}{l}\text { Percent- } \\
\text { age of } \\
\text { carious } \\
\text { teeth in } \\
\text { which } \\
\text { disease } \\
\text { 'healed' }\end{array}$ \\
\hline \multirow{6}{*}{$\begin{array}{l}\text { Urban } \\
\text { London } 1943 \\
\text { London } 1945 \\
\text { Sheffield } \\
1944 \\
\text { Cambridge } \\
1944 \\
\text { Caernarvon } \\
1943\end{array}$} & & & & & \\
\hline & 1870 & $66 \cdot 8$ & $2 \cdot 5$ & $30 \cdot 1$ & $11 \cdot 7$ \\
\hline & 691 & $59 \cdot 1$ & $2 \cdot 8$ & $26 \cdot 5$ & $21 \cdot 5$ \\
\hline & 507 & $74 \cdot 9$ & $4 \cdot 0$ & $30 \cdot 5$ & $10 \cdot 6$ \\
\hline & 531 & $67 \cdot 0$ & $1 \cdot 8$ & $28 \cdot 2$ & $10 \cdot 1$ \\
\hline & 41 & $78 \cdot 9$ & $1 \cdot 3$ & $45 \cdot 3$ & $5 \cdot 3$ \\
\hline Total Urban & 3640 & $66 \cdot 9$ & $2 \cdot 6$ & $29 \cdot 4$ & $12 \cdot 9$ \\
\hline \multirow{3}{*}{$\begin{array}{l}\text { Rural } \\
\text { Cambridge- } \\
\text { shire 1943 } \\
\text { Oxfordshire } \\
1944 \\
\text { Caernarvon- } \\
\text { shire } 1943 \\
\end{array}$} & 298 & $70 \cdot 2$ & $1 \cdot 7$ & $32 \cdot 4$ & $8 \cdot 1$ \\
\hline & 353 & $63 \cdot 6$ & $3 \cdot 1$ & $28 \cdot 4$ & $12 \cdot 5$ \\
\hline & 29 & $71 \cdot 0$ & $1 \cdot 3$ & $38 \cdot 2$ & $12 \cdot 6$ \\
\hline Total Rural & 680 & $66 \cdot 7$ & $2 \cdot 3$ & $30 \cdot 6$ & $10 \cdot 6$ \\
\hline \multirow{2}{*}{$\begin{array}{l}\text { High fluorine } \\
\text { Maldon } 1943 \\
\text { Maldon and } \\
\text { district } \\
1945\end{array}$} & 60 & $39 \cdot 9$ & 0.9 & $10 \cdot 4$ & $22 \cdot 9$ \\
\hline & 139 & $45 \cdot 4$ & $0 \cdot 6$ & $11 \cdot 2$ & $19 \cdot 2$ \\
\hline Grand total & 4519 & $65 \cdot 6$ & $2 \cdot 5$ & $28 \cdot 7$ & $12 \cdot 6$ \\
\hline
\end{tabular}

* Including a few teeth unclassified but with defects nearer to the $G$ - than the $M$-type hypoplasia. 